\title{
An efficient ultrasonic and microwave assisted extraction of organic Henna dye for dyeing of synthetic polyester fabric for superior color strength properties
}

\author{
DOI: $10.35530 / I T .070 .04 .1551$
}

Extracție eficientă cu ultrasunete și microunde a colorantului organic Henna pentru vopsirea materialelor textile sintetice din poliester cu proprietăți superioare de rezistență a culorii

Tehnică de extracție eficientă din punct de vedere energetic și ecologică pentru extracția colorantului organic Henna a fost propusă pentru vopsirea materialelor textile sintetice din poliester, cu proprietăți de rezistență ridicată a culorii, pentru a satisface cererea mondială de procese și produse eficiente din punct de vedere energetic și ecologice, în comparație cu metodele convenționale de extracție cu solvent. Metodele de extracție cu ultrasunete și microunde au fost ulterior analizate și optimizate, în ceea ce privește timpul de extracție și raportul de flotă. Pentru aobserva efectul pH-ului asupra vopsirii naturale a poliesterului cu colorant Henna, vopsirea a fost efectuată la două valoridiferite ale pH-ului. Tehnicile cu ultrasunete și cu microunde au extras semnificativ colorantul Henna, într-un timp mai scurt decât metoda convențională de extracție cu solvent. Rezistențe mai mari ale culorii au fost înregistrate prin extracția cu ultrasunete și microunde a colorantului Henna la vopsirea materialelor textile din poliester.

Cuvinte-cheie: colorant natural Henna, extracție cu microunde, vopsire organică, material textil din poliester, extracție cu ultrasunete

An efficient ultrasonic and microwave assisted extraction of organic Henna dye for dyeing of synthetic polyester fabric for superior color strength properties

An energy efficient and 'green' extraction technique for extraction of organic Henna dye has been proposed for the dyeing of synthetic polyester fabric with high fastness and color strength propertiesto fulfill the world's highest demand towards energy efficient and 'green' processes and products and compared with conventional solvent extraction methods. The ultrasonic and microwave extraction methods were further analyzed and optimized in terms of extraction time and liquor ratio. To observe the effect of $\mathrm{pH}$ on the natural dyeing of polyester with Henna dye, dyeing were carried out at two different $\mathrm{pH}$. Ultrasonic and microwave techniques noticeably extracted Henna dye with in less time than conventional solvent extraction method. High color strength and fastness properties were observed with ultrasonic and microwave extracted Henna dyeing of polyester fabrics.

Keywords: Henna natural dyes, microwave assisted extraction,organic dyeing, polyester fabrics, ultrasonic assisted extraction

\section{INTRODUCTION}

Manufacturing and use of synthetic dyes are a serious distress of creating water contamination and environmental pollution. During manufacturing, synthetic dyes produces various noxious residues in air and water which creates a serious health concerns to workers [1]. Correspondingly during usage, various toxic behaviors of synthetic dyes have been reported specifically carcinogenic and mutagenic [2-3] which leads to the exclusion of various synthetic dyes specially disperse dyes listed in ZDHC (zero discharge of hazardous chemicals programme) [4]. As a result, there is a great resurgence of interest in natural organic dyes to replace toxic synthetic dyes for dyeing of textile materials [5]. Natural sources for colors are nontoxic, ecological and biodegradable [6-7], therefore colorants from natural sources have been established as 'green' alternatives of synthetic dyes [8-10].

Extraction of natural color from their origin is the most important stage in natural dye applications as the efficiency of extraction method strongly influences the color depth and hence the dyeing behavior of the textile material to which it is used. Extraction of organic dyes involves the route to separate colorants from plant sources, which are strongly bound to plant cell membrane. Traditionally, a number of solvents have been used for the separation of color chromophore from the plant material such as acids, alkalis, alcoholsand enzymes with or without Soxchlet apparatus [11-13]. These methods are time consuming [14] and required huge quantity of solvents which due to toxic nature causes environmental problems and eliminate rewards of using natural colors. Moreover, need for solventsremoval entirely from dye solution after extraction due to serious negative effects on dyeing 
and color fastness properties of fabrics, made the extraction and dyeing with natural colors expensive and inefficient [15]. Therefore, to acquire comprehensive benefit of natural resources of dyes as green alternatives of synthetic colorants, it is mandatory to develop and standardize an extraction system which is nontoxic (no use of chemicals), inexpensive, energy efficient, and more environment friendly.

In this concern, advanced technologies such as ultrasonic and microwave has been presented as an energy efficient and environment friendly [16-17] developments for natural color extraction and receive the significant consideration of researchers due to their potential advantages like faster and solvent free extraction [18] over conventional solvent extraction methods [19]. Recently, authors found that ultrasonic [20] as well as microwave extraction [21] as an advanced and efficient techniques for extraction.

Ultrasonic waves rupture the cell membrane by means of forcibility acting shockwaves created with the formation and collapsing of bubbles resulted in improved percolating of color constituent and hence extraction efficiency. On the other hand, microwave irradiation technique for extraction provide efficient colorant extraction by means of microwave heating which specifically heated the microscopic traces of moisture within the plant cell, which in turn generates remarkable pressure on the plant cell wall [19]. The inside pressure resulted in intensive rupturing of the cell wall, and consequently facilitates removal of the targeted color constituents to the water/solvent thus improving the yield.

Henna (Lawsoniainermis Linn) belongs to the family Lythraceae is extensively cultivated in Middle Eastern and Northern African countries. Henna leaves (Lawsoniainermis) has been used as a major source of natural color for human skin, hairs as well as textile fibers due to its antibacterial [22] and UV protection [23] properties. Chemically, Henna lawsone chromophore belongs to the naphthoquinone family with name 2-hydroxy-1,4-naphthoquinone shown in figure 1, a, commercially known as Natural Orange 6. Cheap cost and easy availability of Henna natural dyes made it very popular among natural fibers such as cotton [12], wool [22], and silk [24] due to their higher absorbency. Though, very limited studies are available on the use of Henna dye onmost important synthetic fibresin the world such as polyester [25].
Due to highest demand of polyester fabric [26] and banned on various toxic disperse dyes [4], herein we selected Henna dye as a 'green alternative' to disperse dye for polyester fibre.

In this work, we proposed a novel technique to extract organic colorant from Henna dye by means of energy efficient and inexpensive ultrasonic and microwave techniques. Ultrasonic and microwave assisted extraction of organic Henna dye was subsequently applied over synthetic polyester fabrics and its dyeing characteristics were analyzed. Ultrasonic and microwave assisted extraction of organic Henna dye was optimized to provide ideal conditions to use Henna dye on polyester fibre industrially without any difficulty. The ionic performance of any dye compound and therefore its characteristic color on specific fibre depends on the $\mathrm{pH}$ of the media and hence fibre-dye interactions. Therefore, to observe the chemistry of Henna dye towards polyester fibres at different dye bath $\mathrm{pH}$, two $\mathrm{pH}$ conditions were used to dye the polyester fibre with Henna dye at neutral (7) and acidic (4.5-5) $\mathrm{pH}$. As to our best knowledge, this is the first research report on the ultrasonic and microwave extraction of Henna natural dye for the dyeing of synthetic polyester material. This method of extraction is expected to be a very simple method and aim to provide ready to use dyes for coloration without the need for prolonged post treatments of solvent extraction method.

\section{EXPERIMENTAL}

\section{Materials and equipment}

For the experimental work, Bleached, $100 \%$ polyester fabric of 90 GSM was kindly supplied by Gul Ahmad textile mills, Karachi, Pakistan. Natural Henna leaves were obtained from Badin origin, Pakistan. All chemicals and mordants including ferrous sulfate $\left(\mathrm{FeSO}_{4} \cdot 7 \mathrm{H}_{2} \mathrm{O}\right.$ ), aluminum potassium sulfate (KAl $\left.\left(\mathrm{SO}_{4}\right)_{2}\right)$, sodium Hydroxide, sodium carbonate, acetic acid, andhydrochloric acid used were purchased from Merck. Lemon used as a bio mordant was purchased from the local market, Hyderabad, Pakistan. Dyeing of polyester fabric was carried out at High temperature high pressure dyeing machine (Rapid Labortex $\mathrm{H}-120$, Taiwan). For the extraction of Henna leaves, ultrasonic (US) bath $(40 \mathrm{KHz})$ and household microwave oven of $2.45 \mathrm{GHz}$ frequency was used. To

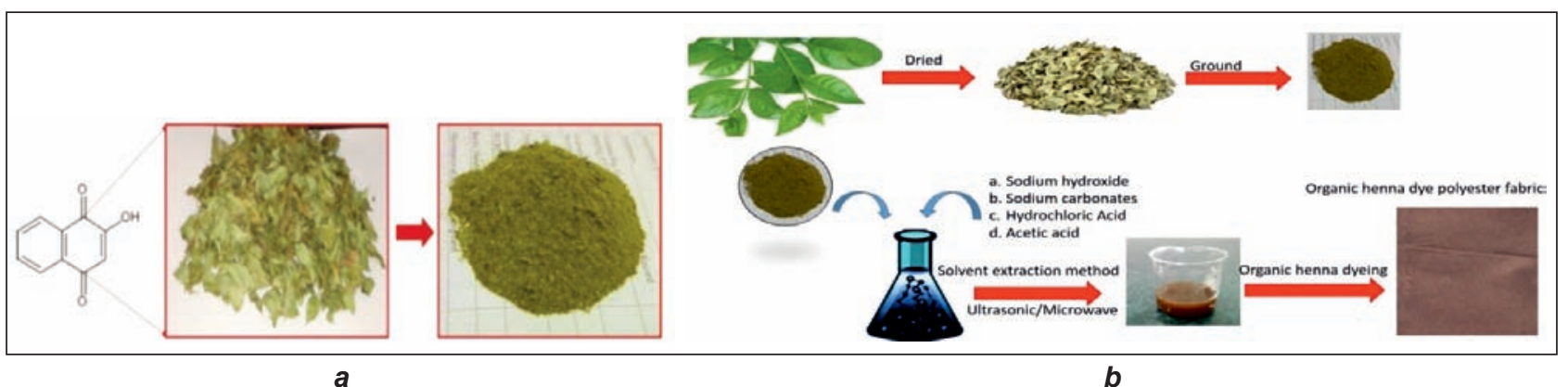

Fig. 1. $a$-chemical structure of Henna Lawsone chromophore; $b$ - layout of extraction of Henna dye 
increase the efficiency of US bath, agitation of ultrasonic bath was executed electrically in local means. The power input was $300 \mathrm{~W}$ and $700 \mathrm{~W}$ for ultrasonic and microwave respectively. Soxchlet evaporator was used to separate water from all the extracted color solutions separately to concentrate the dye solution.

\section{Extractionof natural Henna dye \\ Ultrasonic assisted extraction}

Henna leaves were thoroughly washed with distilled water and then dried under open air for 24 hours followed by oven drying at $50^{\circ} \mathrm{C}$ for two hours. Dried Henna leaves were grounded into powder form by using agate mortar. For the ultrasonic extraction of Henna natural dye, the color was extracted from Henna leaves powder by using an Ultrasonic bath for 30 minutes at $50^{\circ} \mathrm{C}$ [27]. $100 \mathrm{ml}$ of water was used for extraction with the liquor ratio (Henna dye in gram to water in $\mathrm{ml}$ ) 1:20. The extracted color was filtered with tea filter and then the constant amount of water (approximately $30 \mathrm{ml}$ ) was separated by using Soxchlet evaporator for 20 minutes.

\section{Microwave assisted extraction}

For the extraction of Henna dye with microwave, the same procedure was followed as in ultrasonic assisted extraction except that the Henna dye sample was treated in microwave oven of $2.45 \mathrm{MHz}$ and $700 \mathrm{~W}$ power for 4 minutes at boiling temperature.

\section{Solvent assisted extraction}

For comparison studies, solvent extraction of Henna dye was carried out with the exact material as in ultrasonic assisted extraction and treated with sodium hydroxide, sodium carbonate, acetic acid and hydrochloric acid separately for 24 hours at room temperature with the method reported in previous work [28]. The color was also extracted from Henna leaves powder for 24 hours with water without any solvent at room temperature and used as a control extraction method.

\section{Dyeing of Polyester Fabric with natural Henna dye}

The Henna dye color solution from solvent, ultrasonic and microwave assisted extraction was used to dye separately different samples of polyester at $130^{\circ} \mathrm{C}$ for 60 minutes on conventional high temperature and high pressure (HTHP) dyeing machine. To observe the effect of dye bath $\mathrm{pH}$ on the dyeing behavior of Henna dye, dyeing was carried out at two $\mathrm{pH}$ conditions such as acidic (4.5-5) and neutral (7). The extraction method which gave the optimum color strength (K/S) on polyester fabric was further optimized in terms of extraction time and liquor ratio (weight of crushed Henna leaves in gram to water in $\mathrm{mL})$.

\section{Optimization of Ultrasonic and Microwave} assisted extraction of organic Henna natural dye

For the optimization of extraction time, ultrasonic extractions of Henna dye were carried out for various time durations, viz., for 10, 30, 50, 70 and 90 minutes, respectively at $50^{\circ} \mathrm{C}$ temperature with Henna dye to liquor ratio 1:20. All the extracted solutions for different time were used to dye the polyester fabric with the method given above. The extraction which gave the optimum color strength was further utilized to optimize the Henna dye to liquor ratio. For the optimization of Henna dye to liquor ratio, different liquor ratios were used for ultrasonic extraction i-e; 1:20, 1:40, 1:60, 1:80 and 1:100. The extract which gave the optimum color strength (K/S) was further analyzed in terms of fastness properties. The same procedure was followed for the optimization of extraction time and liquor ratio with microwave extraction, with the exception that, the microwave extractions were carried out for 1, 2, 3, 4 and 5 minutes at boiling temperature for time optimization. For the optimization of liquor ratio, the same procedure was followed as discussed for ultrasonic extraction. The schematic illustration of extraction of Henna dyes with ultrasonic, microwave and solvents and fabric dyeing is shown in figure $1, b$.

\section{CHARACTERIZATION}

For the spectrophotometric studies of the polyester dyed fabric, Reflectance values of each dyed sample were measured on a Data color SF600 spectrophotometer with illuminant D65 and UV and specular component included. Each sample was measured at five different locations and the average value was calculated. Using the reflectance value at maximum absorption, the color yield (K/S) was calculated with the Kubelka-Munk equation Eq. 1

$$
\left(\frac{K}{S}\right)_{\lambda \max }=\frac{(1-R)^{2}}{2 R}
$$

$K$ is the absorbance, $S$ - the scattering coefficient and $R$ - the reflection.

\section{RESULTS AND DISCUSSION}

\section{Color strength measurement}

\section{Effect of extraction method}

The results of polyester fabric samples dyed with ultrasonic, microwave and solvent assisted extraction of organic Henna dye presented in figure $2, a$ and $b$ respectively with water as a control extraction process. Higher color strength of polyester fabric dyed with Henna color extracted by ultrasonic (5.5) and microwave (6) was achieved as compared to the control (water) extracted Henna dye (5.2) at acidic pH 4.5-5. On the other hand, solvent extraction method, either acidic or alkaline extraction displayed less color strength as compared to control (water) extracted Henna dye. This might be due to the high reactivity of lawsone in alkaline extraction [12] and hydrolyzation of the Henna lawsone molecule in highly acidic environment. On the other hand, with ultrasonic and microwave extraction of Henna dye, it was possible to achieve same or even more color strength in less time (30 minutes and 4 minutes, respectively) as compared to 24 hours aqueous/solvent extraction. 


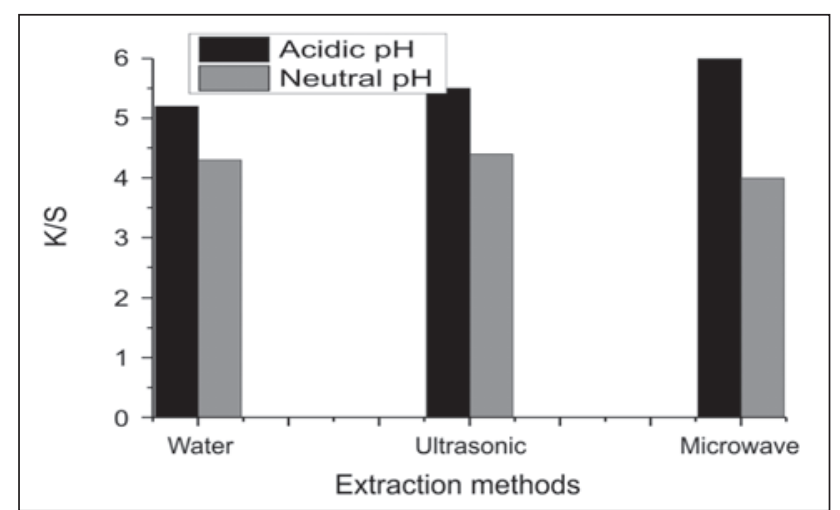

a

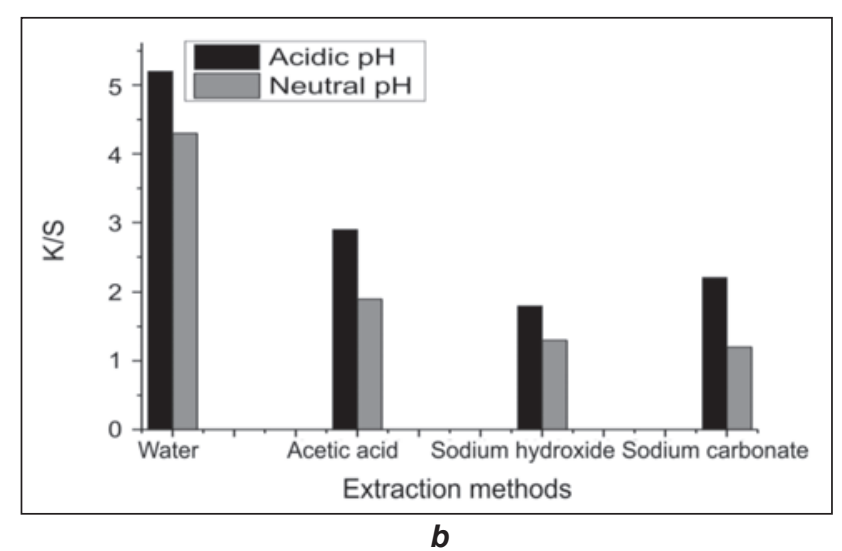

b

Fig. 2. Color strength (K/S) of polyester fabric by: $a$ - ultrasonic, microwave, and $b-$ solvent assisted extraction
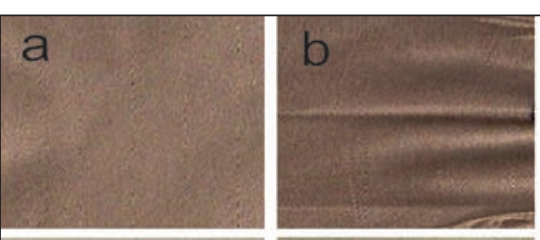

d

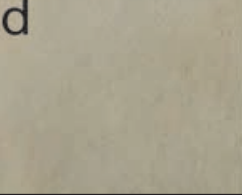

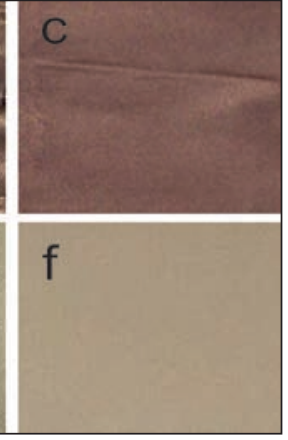
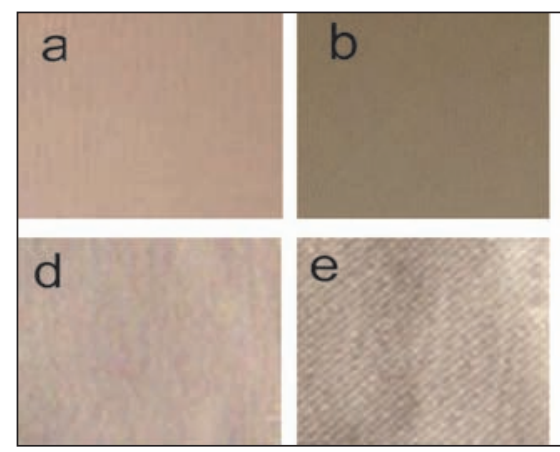

Fig. 3. $a$ - Polyester fabrics dyed at acidic $\mathrm{pH} 4.5-5$ after extraction by: $a$ - water; $b$ - ultrasonic; $c$ - microwave; $d$-sodium hydroxide; $e$ - sodium carbonate; $f$ - acetic acid.

$b$ - Polyester fabrics dyed at neutral $\mathrm{pH} 7$ after extraction by: $a$ - water; $b$ - ultrasonic; $c$ - microwave; $d$-sodium hydroxide; $e$ - sodium carbonate; $f$ - acetic acid

More color strength of microwave extracted polyester fabric is due to the fact that microwaves heating make possible the diffusion of water into the cells of the matrix, leading to better heating and therefore facilitating the transport of compounds into the waterat higher mass transfer rates which was not possible with conventional solvent extraction. Cavitation phenomena as well as mechanical action of ultrasonic energy generate forceful shock waves and power jets to rupture the cell wall of the plant resulted in increased efficiency of extractions as compared to any other solvents used conventionally [17]. Therefore, ultrasonic and microwave extraction of Henna organic dye is acclaimed as an advanced and efficient technique.

\section{Effect of dye bath $\mathrm{pH}$}

Color strength of polyester fabric by all extraction methods at neutral dye bath $\mathrm{pH}(7)$ is less as compared to acidic $\mathrm{pH}(4.5-5)$ as shown in figure $3(\mathrm{~A})$ and $(B)$, respectively. This behavior of Henna dye depends on the ionization and partial solubility of Henna dye. In acidic solution, only $5 \%$ of the lawsone was ionized [29]. However, the used lawsone was replaced by the fibre from solution with the suspended lawsone present as excess of solubility. The partial solubility and very low ionization of Henna dye at acidic $\mathrm{pH}$, made it possible to interact with hydropho- bic polyester fibre (solid solution phenomena). The Henna lawsone chromophore diffused in to the spaces between polyester chains while at the end of the molecule, they wield $\mathrm{OH}$ site that are capable of interacting with polar sites on the substrate. The hydrogen bond is formed between the hydroxyl group of the lawsone molecule and the oxygen of the adjacent polyester fiber chains same like some disperse dyes [30]. On the other hand, at higher dye bath $\mathrm{pH}$, Henna dye ionization increased and it became anionic and repelled by polyester fibre resulted in less dye ability at alkaline $\mathrm{pH}$.

\section{Optimum extraction conditions for Ultrasonic and Microwave \\ Effect of extraction time on the color strength of polyester fabric}

Figure 4 represented the results for the color strength of ultrasonic and microwave extracted Henna dye for different periods of time respectively. It has been observed from the graph that the color strength of polyester fabric increased with increase in the extraction time and reached maximum value of 5.5 and 6 at 30 minutes and 4 minutes for ultrasonic and microwave respectively. This is due to the fact that ultrasonic waves penetrate more deeply into Henna leaves powder resulted in higher mass transfer at 30 minutes until the equilibrium is reached. On the other 


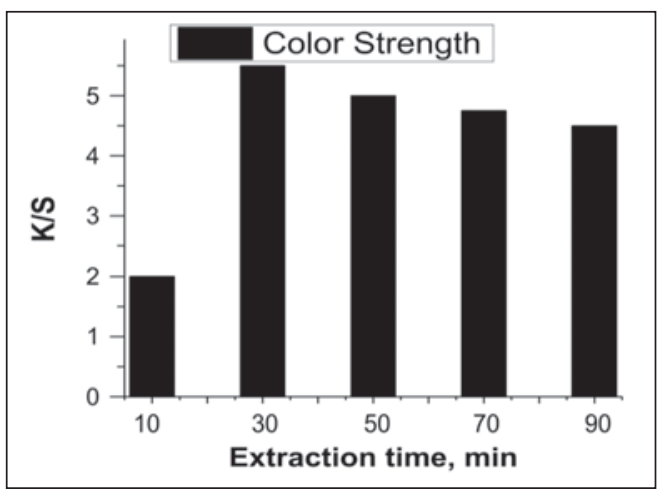

a

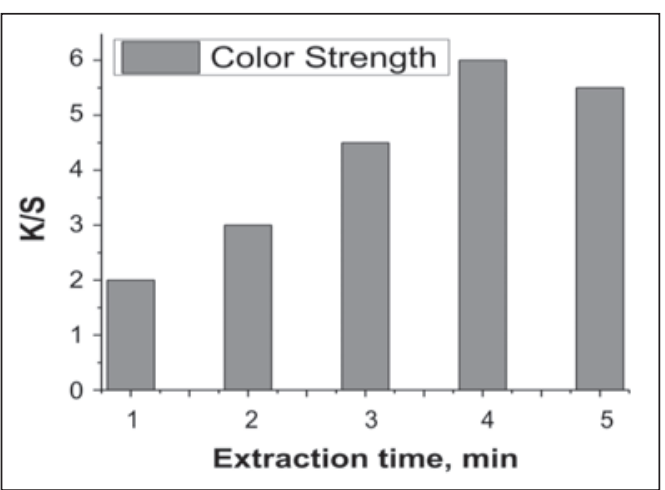

b

Fig. 4. Optimization of time for: $a$ - Ultrasonic extraction; $b$ - Microwave extraction

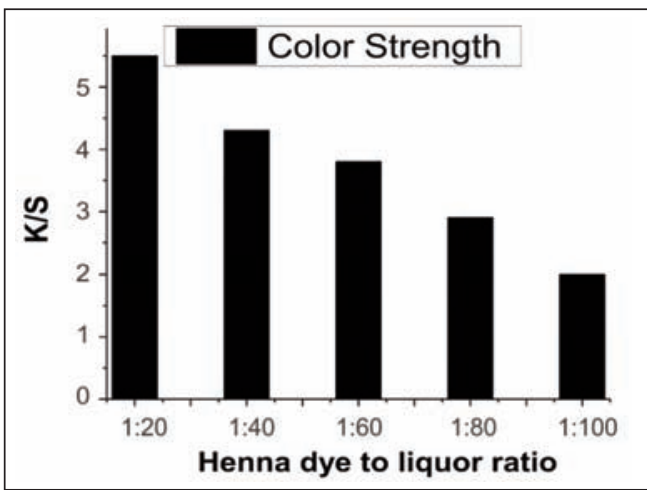

a

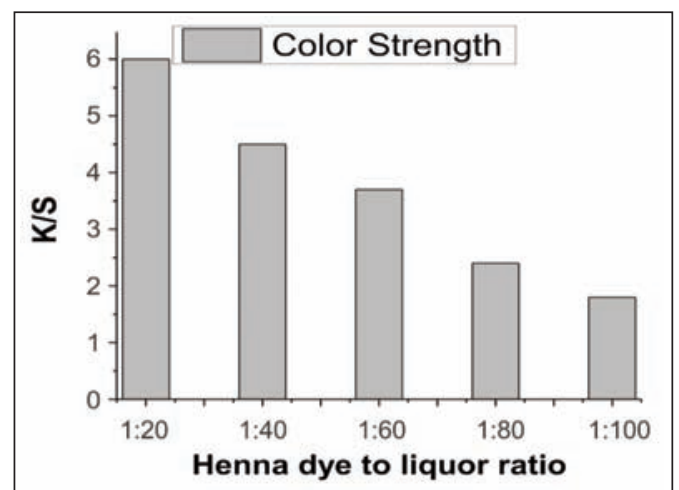

b

Fig. 5. Optimization of Henna dye to liquor ratio for: $a$ - Ultrasonic extraction; $b$ - Microwave extraction

hand, high radiations of microwave are so fast and deep that it needed only 4 minutes for high yield of color component from Henna leaves resulted in deeper shades. A further increase in extraction time resulted in reduction in color strength value by both ultrasonic and microwaves. This may be attributed to the decomposition of coloring component with longer extraction time [31].

\section{Effect of Liquor ratio on the color strength of polyester fabric}

Figure 5 demonstrated the effect of Henna dye to liquor ratio (water) for ultrasonic and microwave respectively. The maximum color strength for both ultrasonic and microwave was achieved at 1:20. As expected, the color strength value of Henna dyed polyester fabric decreased with increasing the liquor ratio and this may be due to the less number of dye molecules available with increased quantity of water for the same weight of fabric.

\section{CONCLUSIONS}

Ultrasonic and microwave assisted extraction of Henna dye has been performed as an energy efficient and solvent free extraction for the dyeing of polyester fabrics. Results revealed that ultrasonic and microwave techniques provided superior color strength properties as compared to results obtained from conventional solvent extraction technique. Ultrasonic and microwave extraction are proved to be efficient in terms of chemicals as these both techniques removed the use of hazardous chemicals in extraction. Ultrasonic and microwave extraction also reduced the time of extraction from hours for conventional solvent extraction methods to 30 minutes and 4 minutes, respectively. The 1:20 liquor ratio gave the optimum color strength on Henna dyed polyester fabric. The presented method of extraction and dyeing of polyester fabric with Henna dye provide a better and proficient route in terms of time, energy, efficiency, and use of unsafe chemicals.

\section{BIBLIOGRAPHY}

[1] Group, W.B., Pollution prevention and abatement handbook. Oil and Gas Development (onshore) Guideline, 1998

[2] Chung, K.-T. andCerniglia, C.E.,Mutagenicity of azo dyes: structure-activity relationships. Mutation Research/ Reviews, In: Genetic Toxicology, 1992, 277(3), pp. 201-220

[3] Carneiro, P.A., et al., Assessment of water contamination caused by a mutagenic textile effluent/dyehouse effluent bearing disperse dyes, In: Journal of Hazardous Materials, 2010, 174(1-3), pp. 694-699 
[4] Das, S., Product safety and restricted substances in apparel, Second Edition ed. 2016, New York: WPI Publishing

[5] Yang, M., et al., Ecological dyeing of silk fabric with Monascus, In: The Journal of the Textile Institute, 2018, pp. 1-6

[6] Karaboyacı, M. and Ş.S. Uğur, Ecological wool dyeing with pulps of lavender, broom, and red wine, In: The Journal of the Textile Institute, 2014, 105 (8), pp. 821-827

[7] Aminoddin Haji, M.N., Sadroddin Qavamnia, S., The use of D-optimal design in optimization of wool dyeing with Juglansregia bark, In: Industria Textila, 2018, 69 (no. 2), pp. 104-110

[8] Sivakumar, V., J. Vijaeeswarri, and J.L. Anna, Effective natural dye extraction from different plant materials using ultrasound, In: Industrial Crops and Products, 2011, 33 (1), pp. 116-122

[9] Sivakumar, V., et al., Ultrasound assisted enhancement in natural dye extraction from beetroot for industrial applications and natural dyeing of leather, In: UltrasonicsSonochemistry, 2009, 16 (6), pp. 782-789

[10] Mansour, R., B. Ezzili, and M. Farouk, The use of response surface method to optimize the extraction of natural dye from winery waste in textile dyeing, In: The Journal of The Textile Institute, 2017, 108 (4), pp. 528-537

[11] Prabhu, K. and M. Teli, Eco-dyeing using Tamarindusindica L. seed coat tannin as a natural mordant for textiles with antibacterial activity, In: Journal of Saudi Chemical Society, 2014, 18 (6), pp. 864-872

[12] Ali, S., T. Hussain, and R. Nawaz, Optimization of alkaline extraction of natural dye from Henna leaves and its dyeing on cotton by exhaust method, In: Journal of cleaner production, 2009, 17 (1), pp. 61-66

[13] Iqbal, J., Bhatti, I.A., and Adeel, S., Effect of UV radiation on dyeing of cotton fabric with extracts of Henna leaves. 2008

[14] Kiumarsi, A., et al., Extraction of dyes from Delphinium Zalil flowers and dyeing silk yarns, In: The Journal of the Textile Institute, 2017, 108 (1), pp. 66-70

[15] Karaboyaci, M., Recycling of rose wastes for use in natural plant dye and industrial applications, In: The Journal of the Textile Institute, 2014, 105 (11), p. 1160-1166

[16] Park, J., et al., Recent advances in ultrasonic treatment: challenges and field applications for controlling harmful algal blooms (HABs), In: Ultrasonics Sonochemistry, 2017

[17] Erdemişsmal, Ö.,Yıldırım, L., and Özdoğan, E., Valorisation of almond shell waste in ultrasonic biomordanted dyeing: alternatives to metallic mordants, In: The Journal of The Textile Institute, 2015, 106 (4), pp. 343-353

[18] Mason, T., Paniwnyk, L., and Lorimer, J., The uses of ultrasound in food technology, In: Ultrasonicssonochemistry, 1996, 3(3), pp. S253-S260

[19] Wang, L. and Weller, C.L., Recent advances in extraction of nutraceuticals from plants, In: Trends in Food Science \& Technology, 2006, 17 (6), pp. 300-312

[20] Febriana, I.D., Gala, S., and Mahfud, M., Ultrasound assisted extraction of natural dye from jackfruit's wood (Artocarpusheterophyllus): The effect of ethanol concentration as a solvent, In: AIP Conference Proceedings, 2017, AIP Publishing

[21] Qadariyah, L., et al., Jackfruit (Artocarpusheterophylluslamk) wood waste as a textile natural dye by micowave-assisted extraction method, In: AIP Conference Proceedings, 2017, AIP Publishing

[22] Nazari, A., Efficient mothproofing of wool through natural dyeing with walnut hull and Henna against Dermestesmaculatus, In: The Journal of the Textile Institute, 2017, 108 (5), pp. 755-765

[23] Alebeid, O.K. and Zhao, T., Review on: developing UV protection for cotton fabric, In: The Journal of the Textile Institute, 2017, 108 (12), pp. 2027-2039

[24] Hasan, M.M., et al., Application of purified lawsone as natural dye on cotton and silk fabric, In: Journal of Textiles, 2015

[25] Baig, G., Indigo dyeing of polyester (PET)-pH effects, In: The Journal of the Textile Institute, 2011, 102(1), pp. 87-92

[26] Azeem, M., et al., Comfort properties of nano-filament polyester fabrics: sensory evaluation, In: Industria Textila, 2018, 69 (1), pp. 3-10

[27] Salehan, N.A.M., Sulaiman, A.Z., and Ajit, A., Effect of temperature and sonication on the extraction of gallic acid from Labisia Pumila (Kacip Fatimah), 2006

[28] Samanta, A.K. and Agarwal, P.,Application of natural dyes on textiles, 2009

[29] Amro, B., James, K., and Turner, T., A quantitative study of dyeing with lawsone, 1993

[30] Khadim Sheikh, H. and Hassan Kazmi, M., Synthesis of novel 1, 2-diol containing azo dyes for polymeric substrates, In: Journal of the Chilean Chemical Society, 2017, 62 (2), pp. 3496-3500

[31] Nagia, F. and El-Mohamedy, R., Dyeing of wool with natural anthraquinone dyes from Fusarium oxysporum, In: Dyes and pigments, 2007, 75 (3), pp. 550-555

Authors:

SAMAD ARAIN RABIA ${ }^{1}$, HUSSAIN PEERZADA MAZHAR ${ }^{1}$ BASHEER ARAIN SAMAD², AYOUB ARBAB ALVIRA ${ }^{3}$

${ }^{1}$ Department of Textile Engineering, Mehran University of Engineering and Technology, Jamshoro, Pakistan

${ }^{2}$ Department of Education, Sindh University, Jamshoro, Pakistan

${ }^{3}$ Department of Organic and Nano Engineering, Hanyang University, South Korea

e-mail: rabia.arain@faculty.muet.edu.pk; mazhar.peerzada@faculty.muet.edu.pk; samama007@yahoo.com; alvira_arbab@yahoo.com

\section{Corresponding author:}

SAMAD ARAIN RABIA

e-mail: rabia.arain@faculty.muet.edu 